\title{
Problematika Guru Pendidikan Agama Islam Peace Education dalam Meningkatkan Prestasi Belajar Siswa Mts. Al-Ikhlashiyah Perampuan Kecamatan Labuapi Lombok Barat Provinsi Nusa Tenggara Barat Tahun Pelajaran 2018-2019
}

\author{
Mastur $^{2}$ \\ Email: mastur1234@gmail.com
}

\begin{abstract}
Abstrak: Begitu pentingnya tugas dan tanggung jawab guru, maka tinggi rendahnya prestasi belajar siswa, bahkan sampai pada mutu pendidikan pada umumnya dikembalikan kepada guru. Sebab keberhasilan proses belajar mengajar ditentukan oleh dua faktor utama yaitu faktor intern dan ekstern. Pengajaran peace education haruslah dengan menerapkan fleksibilitas dan menggunakan pendekatan yang dinamis. Hal tersebut diterapkan agar dapat mengelaborasi tiga ranah peserta didik; kognitif, afektif dan psikomotorik sekaligus. Prestasi belajar merupakan hasil penilaian dari kegiatan belajar anak yang dapat mencerminkan hasil yang dicapai oleh setiap siswa dalam periode tertentu. Prestasi belajar juga dapat diartikan sebagai suatu hasil penilaian yang telah dicapai oleh siswa pada mata pelajar Pendidikan Agama Islam peace education yang berupa nilai hasil ulangan harian yang diperoleh tiap siswa dalam kegiatan belajar mengajar. Proses pengumpulan data merupakan bagian terpenting dalam suatu penelitian, begitu pula dalam penelitian ini, peneliti menggunakan tekhnik relevan dengan jenis penelitian kualitatif. Beberapa tekhnik yang digunakan dalam penelitian ini yaitu: (a) Metode Observasi, (b) Metode Wawancara, dan (c) Metode Dokumentasi. Berdasarkan hasil penelitian dan pembahaswan dapat disimpulkan bahwa 1). Prestasi mata pelajaran Pendidikan Agama Islam Peace Education di MTs. Al-Ikhlashiyah Perampuan Kecamatan Labuapi Lombok Barat rata-rata meningkat, itu terbukti dengan nilai raport masing-masing kelas VII-IX dari 6,5 menjadi 8,0. 2). Soluasi Guru Pendidikan Agama Islam Peace Education dalam mengatasi problema yang dihadapi guru Pendidikan Agama Islam Peace Education guna meningkakan prestasi belajar siswa di MTs. Al-Ikhlashiyah Perampuan Kecamatan Labuapi Lombok Barat yaitu dengan mengadakan bimbingan kepada siswa, itu terbukti dengan setiap hari jum'at diadakannya imtaq dengan melaksanakan shalat dhuha bersama, yasinan bersama dan pemberian nasihat lewat caramah oleh guru agama, membimbing siswa melalui pesantren kilat pada bulan
\end{abstract}

2 Jurnal Mastur, Dosen Tetap STIT Darussalimin NW Praya Lombok Tengah Provinsi Nusa Tenggara Barat 
ramadhan dengan mengadakan lomba-lomba seperti lomba pidato dan baca al-Qur'an.

Kata Kunci: Problematika, Guru Pendidikan Agama Islam, Peace Aducatio, Prestasi Belajar

\section{Pendahuluan}

\section{A. Latar Belakang Masalah}

Di negara kita terdapat tiga lembaga pendidikan yaitu keluarga, sekolah dan masyarakat. Keluarga adalah lembaga pendidikan yang pertama dan utama. Dikatakan pertama karena sebelum ada lembaga pendidikan formal (sekolah), sedangkan disebut utama karena orang tualah yang sebenarnya yang mempunyai tanggungjawab atas pendidikan anaknya. Sekolah merupakan lembaga pendidikan tempat memperoleh pengetahuan melalui proses belajar mengajar yang mencakup mengajar, kurikulum, relasi guru dengan siswa, relasi siswa dengan siswa, waktu sekolah, standar pelajaran, keadaan gedung, metode belajar dan tugas. Sedangkan lembaga pendidikan masyarakat merupakan lembaga pendidikan yang diperoleh melalui lingkungan sosial.

Jadi ketiga lembaga pendidikan di atas sangat penting dalam kehidupan sehari-hari guna meningkatkan sumber daya manusia yang berkualitas. Supaya kwalitas sumber daya manusia tersebut dapat berkembang secara optimal maka perlu adanya guru sebagai tenaga edukatif yang kreatif agar sumber daya manusia benar-benar dapat dipersiapkan untuk menghadapi era globalisasi dan perkembangan IPTEK. Sebab guru adalah salah satu komponen manusiawi dalam proses belajar mengajar, yang ikut berperan dalam usaha pembentukan sumber daya manusia yang potensial di bidang pembangunan. Oleh karena itu, guru merupakan salah satu unsur di bidang pendidikan harus berperan secara aktif dan menempatkan kedudukannya sebagai tenaga profesional, sesuai dengan tuntutan masyarakat yang semakin berkembang, baik dari lapisan masyarakat yang paling maju sampai lapisan masyarakat yang paling terbelakang, guru memegang peranan penting. Hampir tanpa kecuali, guru merupakan satu diantara pembentuk-pembentuk utama calon warga masyarakat. Dalam arti khusus dapat dikatakan bahwa pada setiap diri guru itu terletak tanggungjawab untuk membawa para siswanya pada suatu kedewasaan.

Proses belajar mengajar merupakan inti dari proses pendidikan secara keseluruhan dengan guru sebagai pemegang tanggungjawab utama. Guru berfungsi sebagai pengajar, pendidik dan pembimbing dalam hal ini, termasuk guru agama Islam, sehingga diperlukan adanya berbagai tugas dan tanggungjawab pada diri guru itu sendiri yang senantiasa menggambarkan pola tingkah laku yang diharapkan dalam berbagai interaksinya, baik dengan siswa, sesama guru maupun dengan staf lainnya. 
Begitu pentingnya tugas dan tanggungjawab guru, maka tinggi rendahnya prestasi belajar siswa, bahkan sampai pada mutu pendidikan pada umumnya dikembalikan kepada guru. Sebab keberhasilan proses belajar mengajar ditentukan oleh dua faktor utama yaitu faktor intern dan ekstern. Faktor intern yaitu faktor yang datang dari dalam diri siswa terutama kemampuan yang dimilikinya, motivasi belajar, minat dan perhatian, sikap dan kebiasaan belajar, ketekunan, sosial ekonomi, faktor fisik dan psikis. Sedangkan faktor ekstern yaitu faktor yang datang dari luar diri siswa yaitu lingkungan. Faktor lingkungan yang paling dominan mempengaruhi hasil belajar di sekolah ialah kualitas pengajaran yaitu tinggi rendahnya atau efektif tidaknya proses belajar mengajar dalam mencapai tujuan pengajaran, (Sudjana 1999:39).

Salah satu contoh faktor intern yaitu dalam kegiatan sehari-hari ditemukan adanya kebiasaan belajar yang kurang baik. Kebiasaan belajar tersebut antara lain berupa belajar pada akhir semester, belajar tidak teratur, menyia-nyiakan kesempatan belajar, bersekolah hanya untuk bergengsi, datang terlambat, bergaya pemimpin, bergaya jantan seperti merokok, sok menggurui teman lain dan bergaya minta belas kasihan tanpa belajar. Sedangkan contoh dari faktor eksternal yang bisa menimbulkan siswa tidak berprestasi dengan baik disebabkan oleh faktor lingkungan sosial sekolah seperti guru, para staff administrasi dan temanteman sekelas, bisa juga disebabkan oleh faktor lingkungan sosial siswa seperti masyarakat dan tetangga juga teman-teman sepermainan.

Kedua faktor di atas, mempunyai hubungan yang signifikan dengan hasil belajar siswa. Artinya makin tinggi kemampuan siswa dan kualitas pengajaran guru, diharapkan akan semakin tinggi pula hasil atau prestasi belajar siswa. Sebab prestasi merupakan hasil dari suatu kegiatan yang telah dikerjakan, diciptakan, baik secara individual maupun secara kelompok. (Djamarah, 1994:19). Sedangkan belajar adalah suatu aktivitas yang dilakukan secara sadar untuk mendapatkan sejumlah kesan dari bahan yang telah dipelajari, (Djamarah, 1994:21).

Berdasarkan kerangka pikir di atas, maka perlu dikaji dan diteliti tentang problematika yang dihadapi guru Pendidikan Agama Islam Peace Education dalam meningkatkan prestasi belajar siswa MTs. Al-Ikhlashiyah Perampuan Kecamatan Labuapi Lombok Barat Provinsi Nusa Tenggara Barat Tahun Pelajaran 2018-2019.

\section{B. Rumusan Masalah}

Bertitik tolak dari latar belakang di atas, maka dapat dirumuskan masalah sebagai berikut:

1. Apakah ada problematika yang dihadapi guru Pendidikan Agama Islam Peace Education dalam meningkatkan prestasi belajar siswa MTs. Al-Ikhlashiyah Perampuan Kecamatan Labuapi Kabupaten Lombok Barat Provinsi Nusa Tenggara Barat Tahun Pelajaran 20182019?

2. Apakah solusi yang dilakukan oleh guru Pendidikan Agama Islam mengatasi problema yang dihadapi guru Pendidikan Agama Islam 
Peace Education dalam meningkatkan prestasi belajar siswa MTs. AlIkhlashiyah Perampuan Kecamatan Labuapi Lombok Barat Provinsi Nusa Tenggara Barat Tahun Pelajaran 2018-2019?

\section{Tujuan Penelitian}

Tujuan yang ingin dicaPendidikan Agama Islam dari penelitian ini antara lain:

1. Untuk mengetahui apakah ada problematika yang dihadapi guru Pendidikan Agama Islam Peace Education dalam meningkatkan prestasi belajar siswa MTs. Al-Ikhlashiyah Perampuan Kecamatan Labuapi Kabupaten Lombok Barat Provinsi Nusa Tenggara Barat Tahun Pelajaran 2018-2019.

2. Ingin mengetahui apaka solusi yang digunakan oleh guru dalam mengatasi guru Pendidikan Agama Islam Peace Education dalam meningkatkan prestasi belajar siswa MTs. Al-Ikhlashiyah Perampuan Kecamatan Labuapi Kabupaten Lombok Barat Provinsi Nusa Tenggara Barat Tahun Pelajaran 2018-2019.

\section{Kegunaan Penelitian}

Dari tujuan yang telah dirumuskan dapat diambil kegunaan penelitian sebagai berikut:

\section{Secara Teoritis}

Diharapkan dapat menjadi bahan kajian dalam upaya mengatasi problematika yang dihadapi guru Pendidikan Agama Islam Peace Education dalam meningkatkan prestasi belajar siswa MTs. AlIkhlashiyah Perampuan Kecamatan Labuapi Kabupaten Lombok Barat Provinsi Nusa Tenggara Barat bagi lembaga pendidikan terutama pada mata pelajaran Pendidikan Agama Islam peace education.

\section{Secara Praktis}

a) Diharapkan dapat memberikan solusi terhadap permasalahan yang dihadapi oleh guru-guru dalam mengajarkan pelajaran Pendidikan Agama Islam peace education.

b) Diharapkan dapat memberikan peningkatan dan semangat kinerja guru Pendidikan Agama Islam dalam meningkatkan prestasi belajar siswa.

c) Dari hasil penelitian ini diharapkan bisa menjadi bahan renungan untuk ditindak lanjuti dalam rangka meningkatkan prestasi belajar siswa.

\section{E. Lokasi Penelitian}

Adapun lokasi dalam penelitian ini adalah di MTs. Al-Ikhlashiyah Perampuan Kecamatan Labuapi Kabupaten Lombok Barat Provinsi Nusa Tenggara Barat Tahun Pelajaran 2018-2019. Alasan peneliti pengambil lokasi pada sekolah tersebut karena berdasarkan hasil wawancara dengan guru Pendidikan Agama Islam Peace Education di sekolah tersebut yang menyatakan bahwa problem yang dihadapi guru Pendidikan Agama Islam bisa dipengaruhi oleh beberapa faktor 
diantaranya faktor lingkungan sekolah (seperti guru yang kurang profesional, fasilitas yang kurang mendukung, teman sepermainan) itu sendiri maupun luar sekolah, menurunnya prestasi siswa bisa dipengaruhi oleh siswa itu sendiri seperti malas.

Berangkat dari hal itu, peneliti mengambil penelitian dengan judul problematika yang dihadapi guru Pendidikan Agama Islam Peace Education dalam meningkatkan prestasi belajar siswa MTs. Al-Ikhlashiyah Perampuan Kecamatan Labuapi Kabupaten Lombok Barat Provinsi Nusa Tenggara Barat yang berlokasi di MTs. Al-Ikhlashiyah Perampuan Kecamatan Labuapi Kabupaten Lombok Barat Provinsi Nusa Tenggara Barat. Tepatnya di jalan Gunung Pengsong Kecamatan Labuapi Kabupaten Lombok Barat Provinsi Nusa Tenggara Barat.

\section{F. Problema Guru Pendidikan Agama Islam \\ 1. Pengertian Problema}

Istilah problema/ problematika berasal dari bahasa Inggris yaitu problematic yang artinya persoalan atau masalah. Sedangkan dalam bahasa Indonesia, problema berarti hal yang belum dapat dipecahkan, yang menimbulkan masalah: permasalahan, (Partanto, 1994:276).

Menurut Endang Porwanti (1994:20) menyatakan bahwa problema/ problematika adalah suatu kesenjangan antara harapan dan kenyataan yang diharapkan dapat menyelesaikan atau dapat diperlukan atau dengan kata lain dapat mengurangi kesenjangan itu. Jadi, problema adalah berbagai persoalan-persoalan sulit yang dihadapi dalam proses pembelajaran, baik yang datang dari individu guru (faktor eksternal) maupun dalam proses pembelajaran yang berlangsung di sekolah (faktor intern).

\section{Guru Pendidikan Agama Islam}

Sebelum dijelaskan pengertian guru Pendidikan Agama Islam, terlebih dahulu dijelaskan definisi secara umum. Guru merupakan jabatan atau profesi yang memerlukan keahlian khusus sebagai guru, (Usman, 1995:5). Sedangkan yang dimaksud dengan guru agama adalah orang dewasa yang bertanggungjawab terhadap perkembangan anak didik dengan memberikan pertolongan terhadap mereka dalam perkembangan jasmani dan rohaninya agar mencapai tingkat kedewasaan, mampu berdiri sendiri dan memenuhi tugasnya sebagai hamba atau khalifah Allah maupun sebagai makhluk sosial serta makhluk individu yang mandiri, (Muhaimin, 1993:167). Pendidikan agama adalah usaha-usaha secara sistematis dan progmatis dalam membantu anak didik agar mereka hidup sesuai dengan ajaran Islam, (Zuhairini, 1993:27).

Berdasarkan definisi di atas, dapat difahami bahwa guru Pendidikan Agama Islam adalah orang dewasa yang memiliki keahlian dalam ilmu keguruan yang bertugas untuk mendidik dan mengajar anak hingga memperoleh kedewasaan baik jasmani maupun rohani yang pada akhirnya anak didik tersebut mampu menjalankan 
tugasnya sebagai khalifah Allah SWT, serta mampu berinteraksi sosial di tengah-tengah kehidupan bermasyarakat dan bernegara. Oleh karena itu, guru merupakan salah satu komponen manusiawi dalam proses belajar mengajar, yang ikut berperan dalam usaha pembentukan Sumber Daya Manusia yang potensial di bidang pembangunan, (Sardiman, 2007:125). Oleh karena itu, guru yang merupakan salah satu unsur di bidang kependidikan harus berperan aktif dan menempatkan kedudukannya sebagai tenaga potensial sesuai dengan tuntutan masyarakat yang semakin berkembang dalam arti khusus dapat dikatakan bahwa pada setiap hari guru itu terletak tanggungjawab untuk membawa para siswanya kearah yang lebih baik.

Dengan kata lain pengertian Pendidikan Agama Islam dapat dikatakan sebagai istilah yang digunakan untuk menyebut pengajaran agama sebagai salah satu mata pelajaran di sekolah umum, karena mata pelajaran ini bukan hanya sekedar pengetahuan agama saja, akan tetapi lebih dari itu, yaitu untuk menanamkan ajaran agama islam kepada peserta didik sehingga membentuk suatu kepribadian muslim yang dilakukan secara sadar dan terencana melalui kegiatan bimbingan, usaha pengajaran untuk mencapai tujuan Pendidikan Agama Islam.

\section{Pengertian Pendidikan Agama Islam}

Pengertian pendidikan itu bermacam-macam, hal ini disebabkan karena perbedaan falsafah hidup yang dianut dan sudut pandang yang memberikan rumusan tentang pendidikan itu.

Menurut Sahertian (2000:1) mengatakan bahwa pendidikan adalah usaha sadar yang dengan sengaja dirancangkan untuk mencapai tujuan yang telah ditetapkan. Sedangkan menurut M. Nurul Ihsan Saleh (1996:1) mengatakan bahwa pendidikan merupakan usaha manusia untuk menumbuhkan dan mengembangkan potensipotensi pembawaan baik jasmani maupun rohani sesuai dengan nilainilai yang ada di dalam masyarakat dan kebudayaan. Atau dengan kata lain bahwa pendidikan dapat diartikan sebagai suatu hasil peradaban bangsa yang dikembangkan atas dasar pandangan hidup bangsa itu sendiri (nilai dan norma masyarakat) yang berfungsi sebagai filsafat pendidikannya atau sebagai cita-cita dan pernyataan tujuan pendidikannya. Sedangkan Pendidikan Agama Islam berarti usaha-usaha secara sistematis dan pragmatis dalam membantu anak didik agar mereka hidup sesuai dengan ajaran Islam, (Zuhairani, 1993:27).

\section{Dasar-Dasar Pendidikan Agama Islam}

Sebelum peneliti menguraikan dasar-dasar pelaksanaan Pendidikan Agama Islam, terlebih dahulu dikemukakan dasar-dasar ajaran Islam yaitu al-Qur'an dan Hadits sebagai dasar pokok ajaran Islam. Dari dua pokok inilah ajaran Islam itu dijabarkan kedalam seluruh aspek pendidikan atau ajaran Islam. Selanjutnya tentang dasar-dasar pelaksanaan Pendidikan Agama Islam (di Indonesia) 
mempunyai dasar-dasar yang cukup kuat. Dasar-dasar tersebut dapat ditinjau dari beberapa segi antara lain sebagai berikut:

a) Dasar Hukum

Dasar hukum yaitu dasar-dasar pelaksanaan pendidikan agama yang berasal dari peraturan Perundang-undangan yang secara langsung ataupun secara tidak langsung dapat dijadikan pegangan dalam melaksanakan pendidikan agama di sekolah-sekolah ataupun lembaga-lembaga pendidikan formal di Indonesia.

Adapun dasar dari segi hukum formal tersebut ada 3 macam, yaitu: (a) Dasar Ideal yaitu dasar dari falsafah negara, pancasila dimana sila yang pertama adalah kebutuhan yang maha Esa. Ini mengandung pengertian bahwa seluruh bangsa indonesia harus percaya kepada Tuhan yang maha Esa. Atau tegasnya harus beragama. (b) Dasar struktural/konstitusional yaitu dasar dari UUD 1945 dalam Bab XI pasal 29 ayat 1 dan 2 yang berbunyi: (1). Negara berdasarkan atas ketuhanan yang maha Esa, (2). Negara menjamin kemerdekaan tiap-tiap penduduk untuk memeluk agama dan kepercayaannya itu.

Bunyi dari UUD tersebut di atas adalah mengandung pengertian bahwa bangsa Indonesia harus beragama. Dalam arti orang-orang ateis dilarang hidup di negara Indonesia. Di samping itu negara melindungi umat beragama untuk menunaikan ajaran agamanya dan beribadah menurut agama dan kepercayaanya masing-masing. Oleh karena itu, agar umat beragama tersebut dapat menunaikan ibadah sesuai dengan ajaran agamanya masing-masing, maka dapat diperlukan adanya pendidikan agama yang kuat.

b) Dasar Operasional

Dasar operasional yaitu dasar yang secara langsung mengatur pelaksanaan pendidikan agama di Sekolah-sekolah di Indonesia seperti yang disebutkan pada Tap. MPR no. IV/ MPR/ 1973 yang kemudian dikuatkan kembali pada Tap. MPR No.IV/MPR/ 1978. ketetapan MPR No.II/MPR/1983 tentang GBHN, yang pada pokoknya dinyatakan bahwa pelaksanaan agama secara langsung dimasukkan kedalam kurikulum di sekolah-sekolah, mulai dari sekolah Dasar sampai dengan Universitas Negeri.

c) Dasar Religius

Dasar religius yaitu dasar-dasar yang bersumber dari agama Islam yang tertera dalam ayat Al-Qur'an maupun Hadits. Menurut ajaran Islam, bahwa melaksanakan pendidikan agama adalah merupakan perintah dari Tuhan dan merupakan ibadah kepada-Nya. Dalam Al-Qur'an banyak ayat-ayat yang menunjukkan adanya perintah tersebut antara lain: QS At-Tahrim ayat 6:066, yang berbunyi:

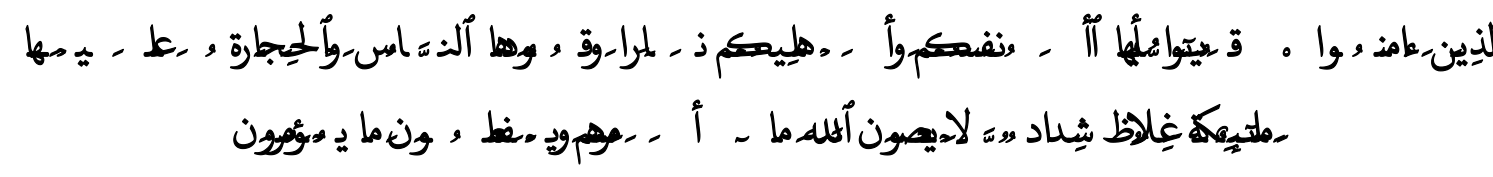

Artinya: 
Hai orang-orang yang beriman, peliharalah dirimu dan keluargamu dari api neraka yang bahan bakarnya adalah manusia dan batu; penjaganya malaikat-malaikat yang kasar, keras, dan tidak mendurhakai Allah terhadap apa yang diperintahkan-Nya kepada mereka dan selalu mengerjakan apa yang diperintahkan.

d) Dasar Sosial Psikologi

Semua manusia dalam hidupnya di dunia ini, selalu membutuhkan adanya suatu pegangan hidup yang disebut agama. Mereka merasakan bahwa di dalam jiwa ada suatu perasaan mengaku adanya zat yang Maha Kuasa, tempat berlindung dan memohon. Hal semacam ini terjadi pada masyarakat primitif maupun modern. Mereka akan merasa tenang kalau dapat mendekat dan mengabdi kepada zat yang Maha Kuasa. Hal semacam ini sesuai dengan firman Allah dalam Q.S. Ar-Ra'ad ayat, 28:013.

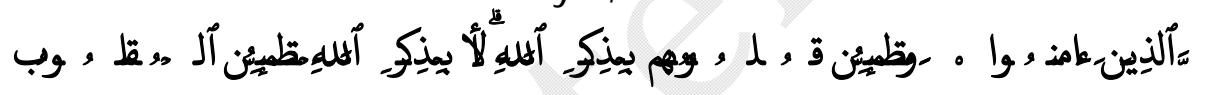

Artinya:

(Yaitu) orang-orang yang beriman dan hati mereka manjadi tenteram dengan mengingat Allah. Ingatlah, hanya dengan mengingati Allah-lah hati menjadi tenteram.

Oleh karena itu, manusia akan selalu berusaha mendekatkan diri dan mengabdi kepada Allah, hanya saja cara mereka mendekatkan diri kepada Tuhan yang berbeda-beda sesuai dengan agama yang dianutnya. Itulah sebabnya, agar dapat mengarahkan mereka kepada pengabdian dan pendekatan diri kepada Allah, maka pendidikan agama harus diadakan.

\section{Tujuan Pendidikan Agama Islam}

Sebelum peneliti mengemukakan tujuan pendidikan agama tersebut terlebih dahulu akan mengemukakan tujuan pendidikan secara umum. Tujuan pendidikan merupakan faktor yang sangat penting, karena merupakan arah yang hendak dituju oleh pendidikan itu. Demikian pula halnya dengan Pendidikan Agama Islam, maka tujuan pendidikan agama itulah yang hendak dicaPendidikan Agama Islam dalam pelaksanaan pendidikan agama tersebut.

Tujuan pendidikan secara formal diartikan sebagai rumusan kualifikasi, pengetahuan, kemampuan dan sikap yang harus dimiliki oleh anak didik setelah selesai suatu pelajaran di sekolah, karena tujuan berfungsi mengarahkan, mengontrol dan memudahkan evaluasi suatu aktivitas sebab tujuan pendidikan itu adalah identik dengan tujuan hidup manusia. Antara dasar dan tujuan terjalin hubungan erat. Dasar pendidikan Islam adalah al-Qur'an dan hadits sedangkan, maka tujuan pendidikan Islam adalah untuk mencapai kwalitas yang disebutkan oleh al-Qur'an dan hadits sedangkan tujuan pendidikan nasional adalah mencapai manusia yang pancasilis maka dasar dari pendidikan nasional adalah pancasila.

Dari uraian di atas tujuan pendidikan agama peneliti sesuaikan dengan tujuan pendidikan agama di lembaga-lembaga pendidikan 
formal dan peneliti membagi tujuan pendidikan agama itu menjadi dua bagian dengan uraian sebagai berikut:

a. Tujuan Umum

Tujuan umum pendidikan agama adalah bertujuan membimbing anak mereka menjadi orang muslim seperti beriman teguh, beramal saleh dan berakhlak mulia serta berguna bagi agama, masyarakat dan negara.

Dari tujuan umum pendidikan di atas berarti pendidikan agama bertugas untuk membimbing dan mengarahkan anak didik supaya menjadi muslim yang beriman teguh sebagai refleksi dari keimanan yang telah dibina oleh penanam pengetahuan agama yang harus dicerminkan dengan akhlak yang mulia sebagai sasaran akhir dari pendidikan agama itu.

b. Tujuan Khusus

Tujuan khusus pendidikan agama adalah tujuan yang disesuaikan dengan pertumbuhan dan perkembangan anak sesuai dengan jenjang pendidikan yang dilaluinya, sehingga setiap tujuan pendidikan agama pada setiap jenjang sekolah mempunyai tujuan yang berbeda-beda, seperti tujuan pendidikan agama di sekolah dasar berbeda dengan tujuan pendidikan agama di SMP, SMA dan berbeda pula dengan tujuan pendidikan agama di perguruan tinggi.

Maka pendidikan agama bertujuan untuk menjadikan anak didik agar menjadi pemeluk agama yang aktif dan menjadi masyarakat atau warga negara yang baik dimana keduanya itu terpadu untuk mewujudkan apa yang dicita-citakan merupakan suatu hakekat, sehingga setiap pemeluk agama yang aktif secara otomatis akan menjadi warga negara yang baik, terciptalah warga negara yang pancasilis dengan sila Ketuhanan Yang Maha Esa.

\section{G. Peace Education dalam Pendidikan Islam}

\section{Pengajaran Peace Education dalam Pendidikan Islam}

Untuk mencapai hasil yang baik dan materi dapat dengan mudah dan dapat dipahami oleh peserta didik, metode pengajaran peace education harus dilakukan dengan cara holistic-partisipatif dengan tidak membatasi diri pada parameter konsep yang kaku. Pengajaran peace education haruslah dengan menerapkan fleksibilitas dan menggunakan pendekatan yang dinamis. Hal tersebut diterapkan agar dapat mengelaborasi tiga ranah peserta didik; kognitif, afektif dan psikomotorik sekaligus.

Dalam pembelajaran peace education, M. Nurul Ikhsan Saleh (Peace Education, 2012:135-136) menguraikan, paling tidak harus melingkupi tiga hal. Pertama, membangun kesadaran akan realita dan konsekuensi dari kekerasan dan pembangunan kesadaran akan terciptanya perdamaian. Kedua, bangunan yang menjadi perhatian dan pengembangan nilai-nilai tanggungjawab, empati, kasih sayang, harapan dan social. Mengembangkan kepekaan moral yang berpuncah 
pada pembangunan kapasitas peserta didik untuk peduli terhadap sesama. Ketiga, mengubah pola pikir dan sikap pribadi dan melakukan sesuatu yang konkret tentang situasi kekerasan.

Agar proses pembelajaran peace education tersebut, dalam konteks sekolah atau lembaga pendidikan, paling tidak ada dua model implementasi pendekatan pendidikan perdamaian (peace education) dan resolusi konflik yang bisa ditubuhkan ke dalam budaya sekolah. Pertama melalui program workshop yang sengaja diciptakan pada tahun ajaran baru dalam rangka pengenalan dan orientasi sekolah. Nilai-nilai perdamaian dan jenis-jenis resolusi konflik yang disampaikan melalui workshop biasanya sarat dengan kegiatan yang menggembirakan melalui sebuah proses bermain, camping, diskusi tentang keragaman dan menonton film-film yang berkaitan dengan penciptaan budaya sekolah yang sehat dan kreatif. Pendekatan dengan model workshop akan memudahkan guru dan fasilitator untuk menciptakan pemahaman dan keterampilan mengelola konflik sekaligus menciptakan rasa damai di lingkungan sekolah. Hasil akhir dari pendekatan ini juga sangat mungkin untuk diadaptasi ke dalam sebuah bentuk kurikulum formal dan menjadi semacam student and teacher code of conduct yang diciptakan dan disepakati bersama. Kedua, setelah mempertahankan student and teacher code of conduct secara tertulis dalam bentuk statute, sekolah kemudian bisa mempertahankannya dengan melakukan model implementasi berikutnya yaitu pengintegrasian materi-materi tentang pendidikan perdamaian (peace education) dan resolusi konflik ke dalam mata pelajaran yang ada di sekolah. Pengintegrasian pengetahuan dan keterampilan mengelola konflik dalam kurikulum sekolah merupakan elemen yang sangat penting dalam manajemen konflik berbasis sekolah.

Beberapa contoh proses integrasi kurikulum pendidikan perdamaian (peace education) dan resolusi konflik ke dalam mata pelajaran misalnya dapat dilakukan bahkan terhadap matematika dasar. Ketika guru sedang menyampaikan topik bahasan tentang menghitung rata-rata pendapatan dan pengeluaran sebuah profesi seperti tukang becak dan guru, menghitung anggaran pendapatan dan pengeluaran daerah, merancang anggaran proyek kelas (untung-rugi), di sini guru dapat melakukan debriefing tentang bentuk-bentuk empati terhadap aneka profesi di masyarakat, transparansi dan akuntabilitas, antikorupsi dan kewirausahaan.

Ketika mengajarkan biologi tentang keanekaragaman hayati (biodiversity) dengan mengenali aneka jenis dan karakteristik makhluk hidup, mengidentifikasi aneka teknik adaptasi terhadap lingkungan, mengenali flora dan fauna yang telah punah dan langka, serta jenis yang masih tinggi populasinya, guru juga dapat memasukkan nilai-nilai tentang perlunya kita merayakan makna perbedaan, adaptasi sosial, kelangkaan, konservasi, kearifan lokal dan kecintaan pada lingkungan hidup. Artinya, ada banyak cara dan cerita 
tentang citra damai dan resolusi konflik yang dapat dielaborasi guru ketika mengajar setiap pelajaran yang diasuhnya. (Lihat Ahmad Baedhowi, pendidikan perdamaian (peace education) dan Resolusi Konflik untuk Sekolah, Media Indonesia, Senin, 01 Maret 2010).

Selanjutnya, pendekatan pengajaran yang holistic-partisipatif berarti memungkinkan peserta didik untuk bertanya, dan berkolaborasi. Peserta didik terlibat dalam dialog dengan guru atau dengan rekan pelajar lain. Praktik mengartikulasikan dan menunjukkan keberagaman pola piker merupakan latihan penting dalam memperluas persepektif. Pembelajaran peace education yang holistic-partisipatif berarti pula memberikan kesempatan bagi peserta didik untuk bekerjasama dalam belajar, bukan bersaing satu sama lain. Pembelajaran ini, selain meningkatkan motivasi belajar, juga meningkatkan hubungan antara peserta didik; menghilangkan sikap individualism, perpecahan dan perasaan prasangka buruk. Dengan demikian, diantara peserta didik antara satu dengan yang lain tidak terasing dan terisolasi. (M. Nurul Ikhsan Saleh, 2012).

Dengan demikian, pada tahapan selanjutnya, dari pembelajaran peace education yang holistic-partisipatif akan mendukung proses pendidikan yang humanis. Pendidikan yang humanis menekankan pertumbuhan social, pribadi dan afektif peserta didik, yang mana individu dari setiap didik diterima apa adanya. Guru juga harus selalu mendorong agar setiap peserta didik agar menghormati satu sama lain, mendorong kepekaan terhadap keragaman di dalam kelas. Hal ini sebagaimana firman Allah dalam surat al-Nahl ayat 90:016.

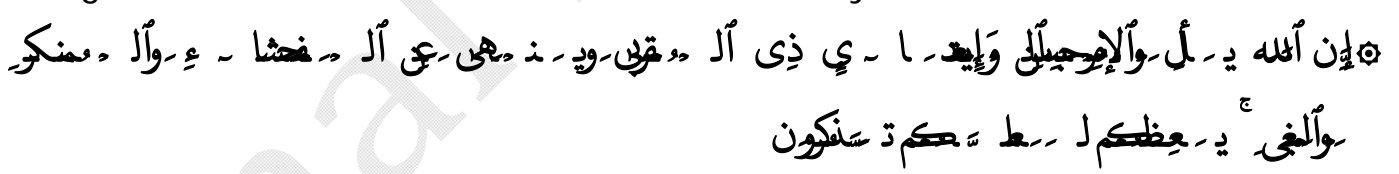

Sesungguhnya Allah menyuruh (kamu) Berlaku adil dan berbuat kebajikan, memberi kepada kaum kerabat, dan Allah melarang dari perbuatan keji, kemungkaran dan permusuhan. Dia memberi pengajaran kepadamu agar kamu dapat mengambil pelajaran. (QS. AlNahl 016: 90).

Dari ayat tersebut jelas sekali bahwa islam menyuruh umatnya agar berlaku adil, berbuat kebajikan dan melarang perbuatan keji, kemungkaran bahkan permusuhan. Maka bagi seorang guru di sekolah menjadi keharusan untuk menenamkan nilai-nilai pendidikan perdamaian (peace education). Dari situlah pembelajaran kemudian membantu peserta didik untuk mengembangkan benih-nenih cinta dan kasih sayang yang diperlukan dalam membangun masyarakat yang damai tanpa diskriminasi tanpa kekerasan.

Begitu pula dengan pengajaran pendidikan islam peace education, tidak ada satu cara pembelajaran yang sempurna dan paling ideal untuk semua tujuan pendidikan, semua ilmu dan materi pembelajaran, semua tahap pertumbuhan dan perkembangan, semua taraf kematangan dan kecerdasan, semua guru dan pendidik, dan 
semua keadaan dan nuansa yang meliputi proses pendidikan itu sendiri. Oleh karena itu, tidak dapat dihindari bahwa seorang guru hendaknya melakukan penggambungan terhadap lebih dari satu cara dalam proses pembelajaran. Hal ini agar proses pembelajaran dapat berlangsung dengan baik dan capat menopang tercapainya tujuan pendidikan, khususnya pendidikan perdamaian (peace education).

\section{Tujuan Peace Education dalam Pendidikan Islam}

Sebagaimana telah saya sampaikan dalam dua tulisan sebelumnya, bahwa peace education merupakan konsep yang masih terus dimatangkan dan dikembangkan. Meskipun kajian tentang pendidikan perdamaian (peace education) telah dan terus menjadi obyek dari suatu pencarian tanpa henti di hampir semua komunitas dan kelompok, terlebih dalam banyak pelatihan, sebagian besar baru pada tahap isu-isu peacebuilding. Padahal, peacebuilding seyogyanya tidak berhenti pada tataran teori atau konsep, tetapi yang jauh lebih penting adalah implementasinya. Karena itu Helene Champagne dalam tulisannya Peacebuilding: toward a global ethic of responsibility, mendefinisikan peacebuilding sebagai praktik yang menantang, oleh karena tujuan ambisiusnya adalah merestorasi perdamaian yang berkesinambungan dalam suatu masyarakat yang terbelah perang dan bagaimana menghindari konflik agar tidak berulang kembali. Kehadiran konflik dan kekerasan perang dalam sejarah manusia senantiasa mengharuskan bahwa yang harus menjadi prioritas utama adalah lembaga pendidikan, sebagai pengelolaan konflik dan perlawanan terhadap bentuk kekejaman dari peperangan.

Dalam beberapa decade terakhir peace education memperoleh momentum dan secara bertahap diterima sebagai suatu bagian yang penting dan diperlukan oleh masyarakat agar terbentuk tatanan kehidupan yang demokratis, berkeadilan dan menjunjung tinggi nilainilai perdamaian atau pendidikan perdamaian (peace education). Aktivitas peace education saat ini, sebagai diurai M. Nurul Ikhsan Saleh, (Peace Education, 2012:122), dapat dikelompokkan menjadi empat kategori. Pertama, peace education sebagai sebagai bentuk transformasi pola pikir; kedua, peace aeducation sebagai pemberdayaan seperangkat keterampilan; ketiga, peace education sebagai promosi dan bentuk penjunjungan tinggi terhadap hak asasi manusia, terutama di negara-negara yang rentan akan konflik dan peperangan; dan keempat, peace education sebagai pembentukan budaya perdamaian dan sebagai advokasi budaya perdamaian di masyarakat.

Keragaman pendekatan dalam pendidikan perdamaian (peace education) menunjukkan bahwa ada keinginan luas dari para pemerhati perdamaian untuk berkontribusi secara persepektif individu guna memperkaya pendekatan yang tengah berkembang sehingga kemudian lumayan sulit mencapai sebuah kesepakatan yang utuh mengenai sifat damai dan penciptaan konsep damai itu sendiri. Oleh karena itu dibutuhkan kerangka yang jelas untuk kerangka teori 
perdamaian yang akan mempertemukan tujuan-tujuan yang berbeda, tetapi saling terkait dan konsep-konsep yang ada menyediakan kerangka kerja yang dibutuhkan untuk program peace education yang komprehensif dan efektif. Akan tetapi, meski tidak ada universalisasi yang disepakati tentang pendekatan yang utuh untuk mencapai perdamaian bukan berarti malah menjadi hambatan akan tercapainya perdamaian yang seutuhnya. Tujuan dari pendidikan perdamaian (peace education) akan membantu peserta didik mencapai pemikiran bahwa perdamaian adalah jalan kehidupan dan kultur universal yang memiliki kontribusi untuk mengambangkan landasan kerja sama dengan masyarakat dan budaya yang berbeda. Dalam hal ini, pendidikan menjadi dasar pembentukan cultur pendidikan perdamaian (peace education) pada peserta didik.

Dengan demikian, peace education memberikan pemahaman kepada peserta didik bagaimana akar dari kekerasan dan kemudian diberikan pengetahuan baru tentang isu kritis sebagai jalan alternative, dengan cara menjaga perdamaian (peacekeeping), menciptakan perdamaian (peacemaking), dan membangun perdamaian (peacebuilding).

Dalam implementasinya, praktik-praktik peacebuilding dewasa ini merefleksikan definisi umum mengenai istilah perdamaian yang sudah diadopsi oleh the United Nation (UN) sejak tahun 1990-an. Pada 1992, Sekretaris Jendral UN, Boutros-Boutros Ghali, telah merilis dokumen yang berjudul An Agenda for Peace. Ghali menyarankan bahwa pembangunan perdamaian adalah satu bentuk pencegahan konflik melalui rekontruksi social dan politik. (M. Nurul Ikhsan Saleh, 2012:123).

Tujuan pendidikan perdamaian (peace education) tersebut sesuai dan relevan dengan tujuan pendidikan Islam, di mana tujuan tertinggi pada pendidikan islam peace education adalah mempersiapkan kehidupan dunia dan akhirat. Tujuan akhir yang hendak dicapai adalah mengembangkan fitrah peserta didik, baik ruh, fisik, kemauan, dan akalnya secara dinamis sehingga akan terbentuk pribadi Muslim sejati yang mengabdi dan merealisasikan segala perintah Allah sebagaimana diatur dalam syariat Islam.

Dalam hal ini, pendidikan Islam menjelaskan posisi peserta didik sebagai manusia di antara makhluk Allah lainnya dan tanggung jawabnya dalam kehidupan ini, hubungan sebagai makhluk sosial dan tanggung jawabnya dalam tatanan kehidupan masyarakat, hubungan manusia dengan alam dan tugasnya untuk memahami hikmah penciptaan dengan cara menjaga harmonisasi alam. Pendidikan Islam diperuntukkan kepada dua dimensi dialektika, yakni dimensi vertikal dan horizontal. Pendidikan Islam menjadi jembatan untuk memahami fenomena dan misteri kehidupan serta upayanya mencapai hubungan dengan Tuhan.

Hal ini sebagaimana diungkapkan Al-Ghazali, yang secara eksplisit menempatkan dua hal penting sebagai orientasi pendidikan. 
Pertama, mencapai kesempurnaan manusia untuk secara kualitatif mendekatkan diri kepada Allah Swt. Kedua, mencapai kesempurnaan manusia untuk meraih kebahagiaan di dunia dan akhirat. Lihat alGhazali, Ihya' Ulum al-Din, (tt: 49-54). Sedangkan dalam dimensi horizontal, pendidikan Islam diharapkan mampu mengembangkan pemahaman peserta didik dalam menghadapi realitas kehidupan, baik yang menyangkut dengan diri, masyarakat atau yang kerap disebut dengan hablum min an-nas, maupun dengan semesta alam (M. Nurul Ikhsan Saleh, 123-124). Artinya peserta didik tidak hanya berorientasi kepada keridhaan Sang Khalik semata, tetapi juga bermakna bagi sesama manusia dan lingkungan kehidupan di sekitarnya. Oleh karena itu, konsep damai dalam pandangan Islam dapat dibagi menjadi empat bagian yang saling berhubungan satu sama lain. Pertama, damai dalam konteks hubungan dengan Allah sebagai Pencipta, yakni kedamaian yang terwujud karena manusia hidup sesuai dengan prinsip penciptaannya yang fitri. Kedua, damai dengan diri sendiri. Ketiga, damai dalam kehidupan bermasyarakat. Hal ini dapat diwujudkan jika manusia berada dalam kehidupan yang bebas dari perang dan diskriminasi, serta diterapkannya prinsip keadilan. Keempat, damai dengan lingkungan, terwujud dari pemanfaatan sumber daya alam bukan hanya sebagai penggerak pembangunan, melainkan pula sumber yang harus dilestarikan demi kesinambungan ekosistem kehidupan.

Dengan demikian, terlihat bahwa tujuan pendidikan Islam yang diambil dari nilai-nilai Islam dapat menciptakan harmonisasi yang berdasarkan perdamaian di antara manusia dengan Allah, manusia dengan manusia lainnya dan alam sekitar. Begitu pun peace education memiliki tujuan menciptakan manusia yang harmonis, damai, dan berkeadaban. (M. Nurul Ikhsan Saleh, 2012:124).

Berdasarkan pemaparan di atas jelas bahwa tujuan peace education dalam pendidikan Islam sejalan dengan ajaran islam yang senantiasa menekankan hidup harmoni dengan menyeimbangkan kehidupan penganutnya baik di dunia maupun untuk akhirat kelak. Keseimbangan kehidupan di dunia direalisasikan dengan mewujudkan tatanan kehidupan damai dengan tidak melakukan diskriminasi, kekerasan dan juga konflik yang mengarah pada peperangan.

\section{H. Problema yang dihadapi guru pendidikan agama islam peace education dalam meningkatkan prestasi belajar}

Dalam proses belajar mengajar di sekolah, guru tidak terlepas dari berbagai masalah atau problem, karena proses belajar mengajar antara guru dengan siswa. Sebagai salah satu contoh cara belajar siswa dipengaruhi oleh relasinya dengan gurunya. Didalam relasi (guru dengan siswa) yang baik, siswa akan menyukai gurunya, juga akan menyukai mata pelajaran yang diberikannya sehingga siswa berusaha mempelajari sebaik-baiknya. Hal tersebut juga terjadi sebaliknya jika siswa membenci 
gurunya, ia segan mempelajari mata pelajaran yang diberikannya, akibatnya pelajarannya tidak maju.

Guru yang kurang berinteraksi dengan siswa secara akrab, menyebabkan proses belajar mengajar itu kurang lancar. Juga siswa merasa jauh dari guru, maka mereka segan berpartisipasi secara aktif dalam belajar. Oleh sebab dalam proses belajar mengajar pelajaran harus didasarkan pada penentuan kebutuhan dasar subjek didik. Untuk dapat memahami kebutuhan dasar subjek didik guru membiasakan diri menggunakan bahasa penerimaan dan menghindari bahasa penolakan maka guru harus belajar mendengarkan aktif. Supaya dapat mendengarkan aktif usahakan pesan yang disampaikan mendapat tanggapan yang tepat. Guru harus sadar bahwa pengajaran bukanlah tujuan, tetapi pengajaran adalah untuk membentuk pribadi terdidik. Jadi guru lebih banyak memberi berbagai pengalaman melalui berbagai kegiatan belajar yang berpariasi dengan cara demikian murid merasakan memperoleh penguatan (renouncement) yang biasa dialami ialah kesulitan belajar siswa dan siswa yang bermasalah. Menghadapi hal-hal seperti itu maka tugas guru ialah mengadakan usaha perbaikan.

Untuk itu guru perlu mendapat support dan bantuan dari supervision. Disamping menciptakan suasana hubungan kemanusiaan, guru perlu menguasai sejumlah keterampilan dalam menemukan cara berfikir siswa dalam proses pembelajaran keterampilan dalam memberi penguatan di samping memiliki cara mengajar yang mendorong siswa untuk membelajar diri sendiri agar siswa memiliki kemampuan untuk mengarahkan diri sendiri (self direction) menentukan diri sendiri (self determination), bertanggung jawab atas diri sendiri (self responsibility), mengendalikan diri sendiri (self control) mendisiplinkan diri sendiri (self discipline) dan menilai diri sendiri (self evaluation) salah satu kemampuan yang perlu diingat salah kemampuan dalam mengelola kelas, yaitu mengatur suasana kelas yang hidup, memberdayakan berbagai sumber belajar sehingga menambah dorongan-dorongan yang kreatif dari para siswa yang belajar.

Seorang guru waktu mengajar, selalu berusaha untuk menciptakan suasana kelas yang menyenangkan. Suasana belajar yang menyenangkan mendorong gairah belajar yang menyenangkan mendorong gairah belajar tinggi. Salah satu masalah dalam menciptakan iklim belajar yang menyenangkan ialah masalah disiplin. Setiap kegiatan proses pembelajaran, guru sering menghadapi prilaku siswa yang bermasalah. Masalah siswa bisa disebabkan karena: (a) Sebab yang bersumber dari siswa itu sendiri. Salah satu sebabnya ialah bahwa ia mempunyai masalah pribadi. Masalah pribadi ini dapat bersumber pada kondisi fisik, misalnya kurangnya pendengaran terganggunya penglihatan dan lain-lain. Bisa juga disebabkan oleh faktor psikologis, misalnya rasa malu, terlalu diminta atau orang tua yang terlalu keras, sehingga siswa merasa tertekan. Sebab lain ialah konsep dari yang mengalami penyimpangan dalam pertumbuhan sejak kecil, sehingga terjadi konsep diri yang berlainan, (b) Sebab yang bersumber dari 
pengaruh teman sepermainan, Misalnya teman sepermainan dari keluarga yang broken home atau yang hidupnya tidak teratur, sebab yang bersumber dari sekolah. Tuntutan sekolah yang bermacam-macam, membeli pakaian seragam, terlambat membayar sekolah, tuntutan membeli buku, dan bermacam-macam tagihan keuangan, (c) Sebab yang bersumber pada guru ialah cara guru mengajar yang tidak menyenangkan dapat menimbulkan penolakan siswa terhadap guru, (d) Sebab yang bersumber dari lingkungan sekitar ialah cara guru mengajar yang tidak menyenangkan dapat menimbulkan penolakan siswa terhadap guru, (e) Sebab yang bersumber dari masyarakat yang lebih luas misalnya keadaan masyarakat yang selalu mengalami kerusuhan, penjarahan, pemerkosaan, perkelahian antara siswa sekolah, dan sebagainya. (Sahertian, 2000:146-147).

Dari uraian di atas dapat disimpulkan bahwa siswa yang bermasalah bisa menimbulkan atau bisa menjadi problem yang dihadapi oleh guru dalam meningkat prestasi belajar siswa. Dalam hal ini usahausaha yang perlu dilakukan untuk mencegah atau mengatasi masalah siswa yang bermasalah terhadap sikap guru.

1. Analisis terhadap sikap guru

Supervisor dapat membantu guru dalam menganalisis faktorfaktor yang menyebabkan timbulnya perilaku yang bermasalah. Berbagai penelitian yang telah menunjukkan bahwa ada hubungan antara sikap guru dengan perilaku siswa yang bermasalah, misalnya guru yang malas, guru yang suka mengkritik guru yang terlalu keras, guru yang suka merokok, dapat menimbulkan rasa tidak senang kepada guru.

2. Analisis terhadap gaya mengajar guru dan gaya belajar siswa

Baik gaya mengajar guru maupun gaya belajar siswa dapat menjadi sebab timbulnya prilaku yang bermasalah dan pelanggaran disiplin. Ada berbagai gaya mengajar guru .

(1) Guru mengajar terlalu cenderung pada pemberian tugas yang terlalu banyak

(2) Gaya mengajar yang mengikutsertakan siswa bersama-sama merancangkan kegiatan belajar antara guru dengan siswa

(3) Gaya mengajar yang berpusat pada keaktifan siswa

(4) Gaya mengajar yang mengutamakan materi pelajaran

(5) Gaya mengajar yang berpusat pada proses pembelajaran

(6) Gaya mengajar yang membangkitkan emosi siswa, (Sahertian, 2000:148).

Selain gaya mengajar guru, juga dapat dianalisis gaya belajar siswa

(1) Gaya belajar setahap demi setahap

(2) Gaya belajar secara intuisi

(3) Gaya belajar yang mengutamakan salah satu alat indra (melihat, mendengarkan, gerak motorik)

(4) Gaya belajar dengan menggunakan bermacam-macam alat indra

(5) Gaya belajar dengan melibatkan emosi 
(6) Gaya belajar tetap, sehingga anak dapat mengeksplorasi sendiri secara relevan

(7) Gaya belajar melalui kegagalan yang dialami

(8) Gaya belajar siswa yang berbeda-beda. (Sahertian, 2000:4-8).

3. Menganalisis lingkungan kelas

Kedudukan kelas juga harus dianalisis seringkali lingkungan kelas yang gersang dan menjadi faktor penghalang dan lingkungan kelas yang gaya dapat merupakan faktor penunjang

4. Kurikulum yang terlalu syarat dan padat perlu dikaji karena dapat merupakan sebab timbulnya pelanggaran disiplin oleh para siswa

5. Menganalisis sikap guru dalam cara mengajar

Perilaku guru dalam proses belajar mengajar dapat pula menimbulkan masalah disiplin, misalnya memperhatikan keluh kesah siswa, memperhatikan perkembangan dan kebutuhan tiap siswa, memperlakukan siswa secara adil, prilaku guru yang demokratis, memberi pujian dan dorongan positif dan sebagainya. Selain cara di atas, cara yang digunakan atau usaha yang dilakukan oleh guru untuk memperbaiki anak-anak bermasalah yaitu dengan jalan membantu guru-guru dalam cara membimbing anak pertama, melalui cara memberi penguatan, yaitu memberi dorongan positif kepada siswa dan kedua, berhati-hati dalam memberi hukuman (punishment).

\section{Pendekatan Penelitian}

Dalam penelitian ini peneliti menggunakan penelitian kualitatif. Karena data dan informasi yang peneliti kumpulkan lebih banyak bersifat keterangan-keterangan atau penjelasan yang bukan berbentuk angka.

Menurut Bogdan dan Taylor (dalam Margono, 2005:36) penelitian kualitatif adalah proses penelitian yang menghasilkan data deskriptif berupa kata-kata tertulis atau lisan dari orang-orang dan perilaku yang diamati. Menurut Margono, bahwa ada beberapa ciri penelitian kualitatif yaitu:
(1) Lingkungan alamiah sebagai sumber data langsung
(2) Manusia merupakan alat (instrumen utama pengumpul data)
(3) Analisis data dilakukan secara induktif
(4) Penelitian bersifat deskriptif analitik
(5) Tekanan penelitian berada pada proses
(6) Pembatasan penelitian berdasarkan fokus
(7) Perencanaan bersifat lentur dan terbuka
(8) Hasil penelitian merupakan kesepakatan bersama
(9) Pembentukan teori berasal dari data
(10) Pendekatan penelitian menggunakan metode kualitatif
(11) Penelitian bersifat menyeluruh (holistik)
(12) Tehnik sampling cenderung bersifat posposive
(13) Makna sebagai perhatian utama penelitian (Margono, 2005:36-42). 
Berangkat dari ciri-ciri penelitian kualitatif di atas, maka dalam penelitian ini digunakan pendekatan kualitatif yang sifatnya natural/alamiah.

\section{J. Kehadiran Peneliti}

Peneliti sebagai orang yang melakukan observasi mengamati dengan cermat terhadap obyek penelitian. Untuk memperoleh data tentang penelitian ini, maka peneliti terjun langsung ke lapangan. Kehadiran peneliti dalam penelitian ini berperan sebagai instrumen kunci yang langsung melibatkan diri dalam kehidupan subyek dalam waktu penelitian yang sudah ditetapkan peneliti untuk memperoleh data sesuai dengan ciri penelitian kualitatif. Sebelum peneliti hadir di lapangan peneliti memperoleh izin terlebih dahulu dari pihak-pihak atau instansiinstansi terkait yang bertanggungjawab sesuai dengan prosedur yang berlaku. Peneliti hadir sebagai pewawancara atau pengumpul data tanpa mempengaruhi kehidupan subyek.

\section{K. Data dan Sumber Data}

Untuk memperoleh data dan informasi yang valid, akurat serta meyakinkan yang berkaitan dengan pelaksanaan pembelajaran pendidikan di MTs. Al-Ikhlashiyah Perampuan Kecamatan Labuapi Lombok Barat Provinsi Nusa Tenggara Barat maka sumber data sangat dibutuhkan. Menurut Suharsimi Arikunto (2006:129) mengatakan bahwa sumber data adalah subyek dari mana data diambil atau diperoleh.

Sumber data dalam penelitian ini adalah orang-orang yang dapat memberikan informasi di lokasi penelitian. Adapun sumber data dalam penelitian ini bisa berasal dari: Kepala MTs. Al-Ikhlashiyah Perampuan Kecamatan Labuapi Lombok Barat Provinsi Nusa Tenggara Barat, guru mata pelajaran Pendidikan Agama Islam Peace Education, siswa-siswa MTs. Al-Ikhlashiyah Perampuan Kecamatan Labuapi Lombok Barat Provinsi Nusa Tenggara Barat dan pihak-pihak yang dapat memberikan informasi tentang problema yang dihadapi guru pendidikan agama islam peace education dalam meningkatkan prestasi belajar siswa MTs. AlIkhlashiyah Perampuan Kecamatan Labuapi Lombok Barat Provinsi Nusa Tenggara Barat.

\section{Metode Pengumpulan data}

Proses pengumpulan data merupakan bagian terpenting dalam suatu penelitian, begitu pula dalam penelitian ini, peneliti menggunakan tekhnik relevan dengan jenis penelitian kualitatif. Beberapa tekhnik yang digunakan dalam penelitian ini yaitu:

\section{Metode Observasi atau Pengamatan}

Observasi merupakan alat pengumpul data yang dilakukan secara sistematis. Observasi dilakukan menurut prosedur dan aturan tertentu sehingga dapat diulangi kembali oleh peneliti dan hasil observasi memberikan kemungkinan untuk ditafsirkan secara ilmiah. 
Secara umum observasi dapat dilakukan dengan cara yaitu: (a). Metode Partisipan Adalah suatu proses pengamatan yang dilakukan oleh observasi dengan ikut mengambil bagian dalam kehidupan orang-orang yang akan di observasi. (b). Observasi non Partisipan merupakan suatu proses pengamatan observer tanpa ikut dalam kehidupan orang yang diobservasi dan secara terpisah berkedudukan sebagai pengamat, (Margono, 2005:161-162).

Dalam penelitian ini akan digunakan tekhnik observasi non partisipan, dimana peneliti akan diambil dalam tekhnik observasi ini antara lain:

(1) Data tentang problema yang dihadapi guru Pendidikan Agama Islam Peace Education di MTs. Al-Ikhlashiyah Perampuan Kecamatan Labuapi Kabupaten Lombok Barat Provinsi Nusa Tenggara Barat.

(2) Data tentang problema yang dihadapi guru pendidikan agama islam peace education dalam meningkatkan prestasi belajar siswa MTs. Al-Ikhlashiyah Perampuan Kecamatan Labuapi Lombok Barat Provinsi Nusa Tenggara Barat.

(3) Data tentang berbagai upaya yang dilakukan untuk mengatasi kendala yang dihadapi guru Pendidikan Agama Islam di MTs. AlIkhlashiyah Perampuan Kecamatan Labuapi Kabupaten Lombok Barat Provinsi Nusa Tenggara Barat.

\section{Metode Wawancara atau intervieu}

Wawancara merupakan percakapan yang dilakukan oleh dua orang atau lebih yaitu wawancara yang akan mengajukan pertanyaan dan orang yang akan diwawancarai yang akan memberikan jawaban atas pertanyaan yang akan diajukan, (Moleong, 2005:186).

Wawancara harus diperoleh dalam waktu yang sangat singkat serta bahasa yang digunakan harus jelas dan teratur. Tekhnik wawancara atau intervieu dapat dibedakan atas tiga jenis yaitu: (a). Pembicaraan formal yaitu wawancara atau intervieu ini sangat tergantung pada pewawancara sendiri tergantung pada spontanitasnya mengajukan pertanyaan kepada yang diwawancarai, (b). Pendekatan menggunakan petunjuk umum wawancara atau intervieu karena jenis ini mengharuskan pewawancara membuat kerangka dan garis besar pokok-pokok yang akan ditanyakan, pokokpokok pertanyaan tidak perlu dipertanyakan secara berturutan. Pelaksanaan wawancara dan pengurutan pertanyaan disesuaikan dengan keadaan responden dan (c). Wawancara buku terbuka, jenis wawancara atau intervieu ini menunjukkan seperangkat pertanyaan baku. Urutan pertanyaan, kata-kata dan cara penyajian sama untuk setiap responden. Wawancara jenis ini bermanfaat apabila yang diwawancarai jumlahnya banyak, (Moleong, 2005:187-188).

Pada penelitian ini akan digunakan teknik wawancara yang menggunakan petunjuk umum wawancara, dimana sebelum bertemu dengan informan, peneliti akan mempersiapkan berbagai hal yang 
akan ditanya kan sehingga berbagai hal yang ingin diketahui dapat lebih terfokus.

\section{Metode Dokumentasi}

Tekhnik dokumentasi adalah mencari data mengenai hal-hal atau variabel yang berupa catatan, transkrip, buku, surat kabar, majalah, parasasti, notulen rapat, lengger, agenda dan sebagainya mengisyarat. (Suharsimi Arikunto, 2006:231).

Jadi dapat dipahami bahwa metode dokumentasi merupakan metode yang penting dalam penelitian ini sebab data-data tertulis sangat menunjang dalam menganalisis data. Data yang akan diambil melalui tekhnik ini yaitu: (a) Data tentang gambaran umum lokasi penelitian yaitu MTs. Al-Ikhlashiyah Perampuan Kecamatan Labuapi Lombok Barat. (b) Dokumen atau arsip yang berkaitan dengan problema yang dihadapi guru pendidikan agama islam peace education selama mengajar di MTs. Al-Ikhlashiyah Perampuan Kecamatan Labuapi Lombok Barat.

\section{Tehnik Analisis Data}

Data yang telah peneliti kumpulkan selama mengadakan penelitian perlu diolah dan dianalisis dengan penuh ketelitian, keuletan dan secara cermat sehingga mendapatkan suatu kesimpulan tentang obyek-obyek penelitian yang baik.

Menurut Nazir (1983:358), Analisis data adalah mengelompokkan, membuat suatu urutan, memanipulasi serta menyingkatkan data sehingga mudah untuk dibaca. Berdasarkan definisi tersebut, analisis data dapat dikatakan sebagai suatu cara untuk mengolah dan memaparkan data secara terorganisir dan sistematis.

Pengolahan data yang diperoleh dengan menggunakan aturanaturan yang ada sesuai dengan metode penelitian yang digunakan. Dalam data ini peneliti menggunakan pendekatan kualitatif yang lebih mengacu pada pengungkapan data sesuai dengan realita dan tidak menggunakan data statistik. Adapun analisis data yang digunakan adalah analisis induktif dan deduktif. Analisis induktif yang artinya dengan menguraikan peristiwa-peristiwa atau data-data yang bersifat khusus untuk kemudian mengumpulkannya dengan bersifat general. Sedangkan analisis deduktif artinya menguraikan peristiwa yang bersifat umum untuk kemudian mengumpulkannya dengan sifat khusus. Jadi, analisis data merupakan langkah lanjutan dari kegiatan pengumpulan data. Data yang terkumpul diolah dan dianalisis dengan maksud agar data itu mempunyai arti dan mampu memberikan keterangan tentang populasi.

\section{N. Keabsahan Data}

Keabsahan data adalah suatu yang dilakukan oleh peneliti dalam rangka untuk membuktikan data yang diperoleh dengan keadaan yang sesungguhnya dan kredibilitas data itu sendiri bertujuan untuk membuktikan apa yang diamati oleh peneliti sesuai dengan pertanyaan yang sebenarnya. Hal ini perlu dilakukan dalam upaya untuk memenuhi 
informasi yang dikemukakan oleh penulis sehingga mengandung nilai kebenaran. Usaha peneliti untuk memperoleh keabsahan data dapat dilakukan dengan beberapa tekhnik diantaranya:

\section{Perpanjangan keikutsertaan}

Keikutsertaan peneliti sangat menentukan dalam mengumpulkan data, keikutsertaan hanya dilakukan dalam waktu yang lama. Dalam hal ini dengan melakukan perpanjangan keikutsertaan peneliti pada hasil penelitian. Dalam penelitian ini peneliti akan berusaha semaksimal mungkin untuk mengumpulkan data sesuai dengan jadwal penelitian yang telah ditentukan. Tetapi jika data yang dibutuhkan masih dirasakan belum cukup maka peneliti akan memperpanjang waktu penelitian agar data yang dikumpulkan dapat dipertanggung jawabkan kebenarannya.

\section{Ketekunan Pengamatan}

Ketekunan pengamatan bermaksud menentukan ciri-ciri dan unsur-unsur dalam situasi yang sangat relevan dengan persoalan atau isu yang sedang dicari dan kemudian memusatkan daripada hal-hal tersebut dengan rinci, (Moleong, 2005:329). Pengamatan sangat dibutuhkan dalam pendekatan penelitian kualitatif dengan tujuan untuk menghindari data yang tidak benar yang diperoleh dari responden yang bisa jadi obyek akan menutup diri terhadap fakta yang sebenarnya. Oleh karena itu ketekunan peneliti dalam mengamati sangat dituntut lebih serius.

\section{Trianggulasi (Gabungan)}

Trianggulasi adalah tehnik pemeriksaan keabsahan data yang memanfaatkan sesuatu yang lebih di luar data itu untuk keperluan pengecekan atau pembanding terhadap data itu. Teknik triangulasi yang digunakan dalam penelitian ini adalah triangulasi sumber, metode dan teori. Adapun jenis triangulasi tersebut adalah:

(1) Triangulasi dengan sumber berarti membandingkan dan mengecek kembali kepercayaan suatu informasi yang diperoleh pada waktu yang cukup dan alat yang berbeda dengan metode kualitatif.

(2) Triangulasi dengan metode wawancara berarti suatu strategi dengan pengecekan derajat kepercayaan penemuan hasil penilaian beberapa sumber data dengan metode yang sama.

(3) Triangulasi dengan teori, berdasarkan anggapan bahwa fakta tertentu tidak dapat diperiksa terhadap kepercayaan dengan satu atau teori yang lebih. (Moleong, 2005:330-331).

\section{Pembahasan}

1. Problema guru pendidikan agama islam peace education dalam meningkatkan prestasi belajar

Sesuai dengan hasil observasi peneliti bahwa problematika yang dihadapi guru pendidikan agama islam peace education dalam meningkatkan prestasi belajar siswa MTs. Al-Ikhlashiyah Perampuan Kecamatan Labuapi Lombok Barat Provinsi Nusa Tenggara Barat 
dapat berupa faktor intern seperti salah satu sikap siswa pada saat belajar mengajar masih rendah karena disebabkan para siswa itu sendiri, terutama kemampuan mereka dalam berfikir dan memahami materi yang telah disampaikan guru. Selain itu kesehatan, intelegensi, perhatian yang masih kurang juga menyebabkan pemahaman siswa sangat minim terutama sekali dalam pemahaman mereka tentang agama, lebih khususnya dalam hal baca tulis al-Qur'an (Observasi, tanggal 25 Januari 2017). Sedangkan faktor ekstern juga berpengaruh seperti kurangnya sarana dan prasarana, karena sarana dan prasarana tersebut menjadi pendukung lancarnya proses belajar mengajar seperti, tidak tersedianya buku paket dari sekolah, sehingga buku yang mereka pakai adalah hasil rangkuman atau diktat yang disusun oleh guru pendidikan agama islam peace education, (Observasi, tanggal 25 Januari 2019).

Menurut hasil wawancara dengan salah satu guru Pendidikan Agama Islam Peace Education bahwa faktor ekstern bisa juga disebabkan oleh materi dan waktu yang tidak sesuai, artinya materi yang akan disampaikan terlalu banyak sedangkan waktu yang diberikan dalam penyampaian materi hanya dua jam dan hanya satu kali pertemuan dalam satu minggu, apalagi melihat materi pelajaran pendidikan agama islam peace education banyak sekali (Sayadi, SE., M.Pd., Selaku Kepala Sekolah, (Observasi, tanggal 25 Januari 2019).

Hasil wawancara peneliti dengan ibu Marwani, S.Pd.I., siswa kelas VIII mengatakan bahwa belajar agama islam menyenangkan, itu tergantung dari cara guru yang menjelaskan materi dan bagaimana siswa menerimanya. Saya kira pelajaran apapun kalau cara menyampaikannya itu baik tentu kami yang menerimanya merasa senang dan cepat mengerti bahkan sebaliknya, kalau guru tidak bisa menjelaskan atau cara menyampaikannya kurang baik tentu temanteman akan mengantuk dan cepat-cepat ingin keluar, (Wawancara, tanggal 27 Juli 2019).

Suniah siswi kelas VIII mengatakan bahwa belajar agama itu penting, karena kita bisa tahu tentang ajaran-ajaran agama dan kelak bisa diamalkan. Belajar agama juga gampang-gampang susah, apalagi belajar baca tulis al-Qur'an, akan tetapi menyenangkan sebab itu merupakan sebuah tantangan, (Wawancara, tanggal 27 Januari 2019). Menurut Zulaiha siswi kelas IX, perasaan tidak senang (minat), ketidakmampuan dan ketidaksiapan mengikuti materi pelajaran di kelas disebabkan oleh teknik atau metode mengajar yang digunkan oleh guru kurang bervariasi atau hanya monoton menggunakan satu metode saja dan beberapa guru kadang dalam menyampaikan mata pelajaran terlalu serius dan tanpa ada sikap humoris, sehingga kadang membuat atau menimbulkan kebosanan. Sedangkan faktor ekstern juga disebabkan oleh faktor keluarga dan masyarakat seperti cara pendidikan orang tua pada anak, hubungan orang tua dengan anak dan contoh teladan atau bimbingan yang dilakukan orang tua. Di samping itu, hal lain dari faktor keluarga yang juga menyebabkan 
kesulitan ekonomi keluarga baik keadaan ekonomi yang kurang (miskin) maupun kelebihan (kaya).

Permasalahan keluarga yang dirasa berat dan sangat mempengaruhi kegiatan belajar adalah seperti kondisi perekonomian keluarga yang masih kurang walaupun bisa membiayai sekolahnya, tetapi kurang memenuhi kebutuhan hidup. Begitu juga dengan faktor masyarakat juga berpengaruh dalam meningkatkan prestasi belajar anak seperti salah satunya teman bergaul, kondisi lingkungan yang kurang kondusif.

Berdasarkan pendapat para guru dan sebagian siswa di atas jelaslah bahwa faktor intern dan ekstern tersebut menjadi problema bagi guru pendidikan agama islam peace education dalam meningkatkan prestasi belajar masing-masing siswa di sekolah bahkan disebabkan juga oleh keadaan sarana dan prasarana pendukung proses belajar mengajar di kelas.

\section{Prestasi mata pelajaran Pendidikan Agama Islam Peace Education}

Akhir dari proses belajar mengajar yaitu proses penilaian atau evaluasi. Penilaian atau evaluasi dapat dilakukan dengan menggunakan tes tertulis dan tes lisan, penilaian atau evaluasi memiliki peran yang sangat penting dalam proses belajar mengajar, sebab kita mengetahui tingkat kemajuan belajar siswa, dengan begitu guru atau pendidik bisa mempunyai gambaran tentang sejauhmana keberhasilannya dalam mendidik. Selain itu sikap keseharian para siswa di sekolah sangat sopan terutama kepada bapak/ibu guru, mereka juga disiplin, bahkan setiap bertemu dengan semua guru setiap siswa selalu mengucapkan salam (Observasi, tangga 25 Januari 2019).

Sedangkan hasil observasi lain setiap siswa ketika belajar Pendidikan Agama Islam Peace Education para siswa selalu memperhatikan dan mendengar dengan baik apa yang menjadi teguran dari guru dalam kelas maupun di luar kelas, ketika jam masuk kelas semua siswa sudah masuk dan tidak ada yang masih keliaran di luar jam pelajaran. Sebelum bel istirahat jam pulang dan ketika waktu shalat dzuhur setiap siswa yang bertugas segera melaksanakan tugas masing-masing di mushalla sesuai dengan perintah dari petugas mushalla (Observasi, 25 Januari 2019).

Uswatun Khasanah, S.Ag, juga menegaskan bahwa dengan adanya Pendidikan Agama Islam Peace Education di sekolah ini banyak sekali kita melihat peningkatakan keimanan yang ditunjukkan oleh siswa-siswi ini disebabkan setiap pagi Jum'at kita diberikan imtaq secara bergiliran yang dimulai dari pihak guru dan kelas secara bergiliran. Sehingga kita dapat melihat keaktifan siswa dalam hal mempelajari agama Islam karena langsung dipraktekkan di depan teman-temannya (peserta imtaq) (Uswatun Khasanah, S.Ag., selaku guru Pendidikan Agama Islam Peace Education kelas VIII, Wawancara, tanggal 27 Januari 2019). 


\section{Solusi Guru Pendidikan Agama Islam Peace Education dalam mengatasi problema guru pendidikan agama islam guna meningkatkan prestasi belajar}

Sesuai dengan problema yang dihadapi oleh guru Pendidikan Agama Islam, solusi yang perlu dilakukan untuk mengatasi problema tersebut adalah:

a) Seorang guru, lebih menganalisis sikapnya dalam memberikan materi baik materi yang berkaitan dengan kehidupan siswa sehari-hari seperti menjalin hubungan tali silaturrahmi dan beretika yang benar dan mampu menganalisis faktor-faktor yang menyebabkan timbulnya prilaku yang bermasalah. Sebaiknya dalam mengevaluasi siswa baik secara lisan maupun secara tulisan juga ditekankan pada pratek ibadah shalat dan hapalan ayat-ayat al-Qur'an (Uswatun Khasanah, S.Ag., selaku guru Pendidikan Agama Islam Peace Education kelas VIII, Wawancara, Tanggal 27 Juli 2019).

b) Menganalisa cara mengajar, maksudnya cara mengajar dalam proses belajar mengajar dapat pula menimbulkan masalah. Oleh sebab itu, guru harus memperhatikan bagaimana cara mengajar yang baik. Karena cara mengajar guru yang tidak sesuai dengan materi yang diajarkan maka siswa tidak tertarik untuk mengikuti pelajaran tersebut. Cara mengajar itu juga disesuaikan dengan waktu belajar siswa seperti belajar di waktu siang lebih ditekankan pada praktek seperti praktek ibadah dan praktek hafalan agar dapat diterapkan dalam kehidupan mereka seharihari (Marwani, S.Pd.I., selaku guru Pendidikan Agama Islam kelas IX, Wawancara, Tanggal 27 Januari 2019).

Sesuai dengan hasil wawancara peneliti, problema guru pendidikan agama islam peace education dalam meningkatkan prestasi belajar siswa bisa di atasi dengan mengadakan bimbingan kepada siswa, itu terbukti dengan setiap hari jum'at diadakan imtaq dengan melaksanakan shalat dhuha secara bersama, yasinan bersama dan pemberian nasihat lewat ceramah oleh guru agama (Marwani, S.Pd.I., selaku guru agama Islam kelas IX, Wawancara, tanggal 27 Januari 2019).

Uswatun Khasanah, S.Ag., juga menambahkan, siswa-siswi dibimbing melalui pesentren kilat pada bulan Ramadhan yaitu dengan mengadakan lomba-lomba seperti lomba pidato, baca al-Qur'an. Dengan bimbingan seperti itu siswa semakin aktif dalam hal belajar agama Islam (Uswatun Khasanah, S.Ag., Selaku guru agama Islam kelas VIII, Wawancara, Tanggal 27 Januari 2019).

Berdasarkan pendapat beberapa guru pendidikan agama islam peace education di atas dapat disimpulkan bahwa problema yang dihadapi guru dalam meningkatkan prestasi belajar siswa di MTs. AlIkhlashiyah Perampuan Kecamatan Labuapi Kabupaten Lombok Barat Provinsi Nusa Tenggara Barat disebabkan oleh faktor intern seperti, kebiasaan, sikap siswa dalam proses belajar mengajar dan juga 
disebabkan oleh faktor esktern seperti sarana dan prasarana pembelajaran, materi pembelajaran.

\section{P. Kesimpulan} bahwa:

Berdasarkan hasil penelitian dan pembahaswan dapat disimpulkan

1. Problema yang dihadapi guru pendidikan agama islam peace education dalam meningkatkan prestasi belajar siswa di MTs. AlIkhlashiyah Perampuan Kecamatan Labuapi Kabupaten Lombok Barat Provinsi Nusa Tenggara Barat adalah sikap siswa pada saat belajar mengajar masih rendah karena disebabkan para iswa itu sendiri, dan kurangnya sarana dan prasarana pendukung untuk lancarnya proses belajar mengajar.

2. Prestasi mata pelajaran Pendidikan Agama Islam Peace Education di MTs. Al-Ikhlashiyah Perampuan Kecamatan Labuapi Lombok Barat Provinsi Nusa Tenggara Barat rata-rata meningkat, itu terbukti dengan nilai raport masing-masing kelas VII-IX dari 6,5 menjadi 8,0.

3. Soluasi Guru Pendidikan Agama Islam Peace Education dalam mengatasi problema yang dihadapi guru Pendidikan Agama Islam Peace Education guna meningkakan prestasi belajar siswa di MTs. AlIkhlashiyah Perampuan Kecamatan Labuapi Kabupaten Lombok Barat Provinsi Nusa Tenggara Barat yaitu dengan mengadakan bimbingan kepada siswa, itu terbukti dengan setiap hari jum'at diadakannya imtaq dengan melaksanakan shalat dhuha bersama, yasinan bersama dan pemberian nasehat lewat caramah oleh guru agama, membimbing siswa melalui pesantren kilat pada bulan ramadhan dengan mengadakan lomba-lomba seperti lomba pidato dan baca al-Qur'an.

\section{Q. Saran-saran}

Bertolak dari kenyataan-kenyataan yang dialami oleh siswa-siswi dalam merealisasikan problema yang dihadapi guru pendidikan agama islam peace education dalam meningkatkan prestasi belajar siswa di MTs. Al-Ikhlashiyah Perampuan Kecamatan Labuapi Kabupaten Lombok Barat Provinsi Nusa Tenggara Barat maka penulis dapat memberikan saransaran kepada:

1. Bapak Kepala Sekolah MTs. Al-Ikhlashiyah Perampuan Kecamatan Labuapi Lombok Barat Provinsi Nusa Tenggara Barat

Diharapkan kepada bapak kepala sekolah agar dapat memberikan bimbingan dan penyuluhan kepada guru untuk mengarahkan setiap siswa dalam membina akhlaqul karimah serta kedisiplinan siswasiswi

2. Guru dan Staf MTs. Al-Ikhlashiyah Perampuan Kecamatan Labuapi Lombok Barat Provinsi Nusa Tenggara Barat

Bagi guru diharapkan untuk tetap memberikan yang terbaik kepada setiap siswa mengenai proses belajar mengajar agar dapat meningkatkan prestasi siswa. Dan guru bidang studi pendidikan agama islam peace education, agar memperhatikan kondisi siswa 
dalam proses belajar mengajar baik dalam menyampaikan materi pelajaran maupun dalam bentuk praktek dan harus bisa menganalisis sikap-sikapnya dalam arti guru harus bisa menganalisis faktor-faktor yang menyebabkan timbulnya prilaku yang bermasalah.

3. Kepada Orang tua atau wali murid

Kepada orang tua atau wali murid diharapkan ikut aktif di dalam membimbing anak-anaknya di rumah, sehingga dapat berhasil dalam meningkatkan prestasi belajar di sekolah, mengajarkan anak untuk berdisiplin dalam mengatur waktu.

4. Kepada siswa-siswi MTs. Al-Ikhlashiyah Perampuan Kecamatan Labuapi Lombok Barat Provinsi Nusa Tenggara Barat Tahun Pelajaran 2018-2019

Diharapkan kepada semua siswa-siswi MTs. Al-Ikhlashiyah Perampuan Kecamatan Labuapi Lombok Barat untuk lebih taat pada tata tertib yang telah dibuat oleh sekolah agar kedepannya lebih tertib dalam menuntut ilmu.

\section{Daftar Rujukan}

Arikunto, Suharsimi. 1996. Administrasi Pendidikan. Cet-15 Jakarta: Mutiara Sumber Widya.

Djamarah, Prestasi Belajar Dan Kompetensi Guru, Surabaya, Usaha Nasional: 1994.

M. Nurul Ikhsan Saleh, Pembelajaran peace education, (Peace Education, 2012:135-136)

Margono, 2005. Metode Penelitian Pendidikan. Jakarta: Rineka Cipta.

Moleong, Lexi, 2005. Metodelogi Penelitian Kualitatif. Bandung: Remaja Rosdakarya.

Muhibbin Syah, Psikologi Pendidikan dengan Pendekatan Baru (Bandung: Remaja Rosdakarya, 2007).

Nasution, 2005. Berbagai Pendekatan Dalam Proses Belajar Dan Mengajar. Jakarta: Bumi Aksara.

Nazir, Muh, 1983. Metode Penelitian. Jakarta: Ghalia Indonesia.

Partanto dan Yuwono (1994). Kamus Bahasa Indonesia, Arkola, Surabaya.

Sahertian, Piet, 2000. Konsep Dasar dan Teknik Supervisi Pendidikan dalam Rangka Pengembangan Sumber Daya Manusia. Jakarta : Rineka Cipta.

Sardiman, 2007. Interaksi dan Motivasi Belajar Mengajar. Jakarta: Raja Grapindo Persada.

Sudjana, Nana. 1999. Dasar-dasar Proses Belajar Mengajar. Bandung: Sinar Baru Algensido Offset.

Suharsimi, Arikunto. 2006. Prosedur Penelitian Suatu Pendekatan Praktek, Edisi Revisi. Jakarta: Rineka Cipta.

Supardi, 2006. Metodologi Penelitian. Mataram: Yayasan Cerdas Press. Syah, Muhibbin, 1997. Psikologi Belajar.Jakarta: PT. Raja Grapindo Persada. Undang-Undang Sistim Pendidikan Nasional, 2006, Jakarta: Pustaka Pelajar. Usman, dkk. 2001. Upaya Optimalisasi Belajar Mengajar, Bandung: PT. Remaja Rosdakrya. 
Uzer Usman, Muhammad, 1995. Menjadi guru profesional. Bandung: Remaja Rosdakarya Offset.

Zuhaerini, 1983. Metodik Khusus Pendidikan Agama. Surabaya: Usaha Nasional. 